\title{
Performance Evaluation of Developed Manually Operated Rotary Weeder for Vegetable Crops
}

\author{
Satish Kumar ${ }^{*}$, Ashok Kumar and Sanoj Kumar \\ Department of Agricultural Engineering, Bihar Agricultural College, \\ Sabour, Bhagalpur, (Bihar) - 813210, India \\ *Corresponding author
}

\section{A B S T R A C T}

Weeding is one of the major control operations in the vegetable crops. The traditional method of weed control is to remove the weed manually by a Khurpi or Spade. This is a very time consuming process. Due to shortage of agricultural labour in peak season, farmers cannot compete weeding in time. Mechanical weeding keeps the soil surface loose, which results in better aeration and moisture conservation. In our country the average land is about $0.5 \mathrm{ha} /$ farmer so, the use of power weeder is not economical and also it is not useful because in standing crop we have to maintain the row to row as well as plant to plant distance. The use of power weeder gives better yield but it is very costly and

\section{Keywords}

Weeds, Weeding efficiency, Field capacity, Moisture content.

\section{Article Info}

Accepted:

28 September 2017

Available Online:

10 November 2017 our farmer cannot afford it. So putting all the gaps a manually operated rotary weeder has been developed by keeping view the cost is low as well as it gives better removal of weeds in vegetative crops. The power is generated for weeding purpose from ground by using a drum. The drum is mounted on a shaft, which moves when drum moves. A bicycle chain wheel is also mounted on that shaft which is connected to the free wheel, which is mounted on pinion shaft through a chain. So when drum moves the pinion shaft as well as tine mounted on pinion shaft also with more peripheral velocity due to difference in number of teeth of chain wheel and gear wheel. The rotary blade enables cutting of weeds and integrating it into soil. The width of coverage of weeder is more than $30 \mathrm{~cm}$ and depth of operation can be adjusted. The weeding efficiency of developed weeder was found as 80 $\%$, at soil moisture content level of $16 \%$. The $\%$ plant damaged was found at this weeding efficiency in between 0.6 to $1.2 \%$. The performance of developed weeder has been analysed on $16 \%$ to $19 \%$ soil moisture content in Tomato, Bringal and okra crops and result shows that weeding efficiency increases with decrease in soil moisture content. Maximum weeding efficiency is obtained at $1.5 \mathrm{Km} / \mathrm{h}$ speed of operation and $35 \mathrm{~mm}$ depth of operation. The observed field capacity of weeder has been found $0.042 \mathrm{ha} / \mathrm{h}$ at $1.5 \mathrm{~km} / \mathrm{h}$ speed of operation at a depth of $35 \mathrm{~mm}$. The cost of weeding operation by using manually operated rotary weeder was calculated at Rs. 16221/ha which was $60 \%$ lower than the conventional method of weeding.

\section{Introduction}

A weed is essentially any plant which grows where it is unwanted. A weed can be thought of as any plant growing in the wrong place at the wrong time and doing more harm than good (Parish, 1990). It is a plant that competes with crops for water, nutrients and light. This can reduce crop production. Some weeds have beneficial uses but not usually 
when they are growing among crops. Weeds decrease the value of land, particularly perennial weeds which tend to accumulate on long fallows; increase cost of cleaning and drying crops (where drying is necessary). Weeds waste excessive proportions of farmers' time, thereby acting as a brake on development (Lavabre, 1991). Weeding is the removal of unwanted plants in the field crops. Mechanical weed control is very effective as it helps to reduce drudgery involved in manual weeding, it kills the weeds and also keeps the soil surface loose ensuring soil aeration and water intake capacity.

Weeding is an important but equally labour intensive agricultural unit operation. There is an increasing interest in the use of mechanical intra-row weeders because of concern over environmental degradation and a growing demand for organically produced food. Today the agricultural sector requires non-chemical weed control that ensures food safety. Consumers demand high quality food products and pay special attention to food safety. Through the technical development of mechanisms for physical weed control, such as precise inter-and intra-row weeders, it might be possible to control weeds in a way that meets consumer and environmental demands. These mechanisms contribute significantly to safe food production (Pullen and Cowell, 1997; Fogelberg and Kritz, 1999; Kurstjens and Perdok, 2000; Blasco et al., 2002).

\section{Weed control methods}

Weed control is one of the most expensive field operations in crop production. Indeed, the detrimental effects of weeds in agriculture in developing countries far exceed those of all crop pests. Njoku (1996) reported that uncontrolled weeds growth reduces yield of the principal crops while untimely weeding reduces the returns from the overall investments in the production of crops. Igbeka (1984) reported that timeliness rather than frequency of weeding is a major determinant of effective weed control.

Anyawu et al., (1976) also reported that biological control of weeds includes the use of cover crops and leguminous which are grown in association with the crops. The cover crops creep on the land to cover the soil, thereby preventing development of weeds by chocking them out. The use of mucuna mulch can be used as an effective supplement with mechanical weed control. The effectiveness of supplementing mucuna mulching weed control must be considered with appropriate hand-pulling of weed using a special V-shaped hoe and mowing weeds with about a $2-\mathrm{kW}$ engine mower.

Kepner et al., (1978) claimed that mechanical method of weed control is the best with little or no limitation because of its effectiveness. According to Kepner et al., (1978) and Buckingham (1976), the primary objective of row crop cultivation is to enhance the use of farm machinery for eliminating weeds from the crop land. The effect of this method is to promote plant growth and better quality crops.

However, the use of such machine is not common and the availability of a mechanical weeder is scarce. In order to complete weeding operation with in available period of time, farmers have to engage more labour and hence it leads to labour scarcity and increased cost. Altough works had been done on tractor operated weeding implements but these implements are costly and for large fields. As well as in India the farmer has about 0.5 ha land for agriculture. Therefore there was requirement of developing such type of weeding implement suitable for small fields. Under these circumstances a "Manually Operated Rotary Weeder" were developed for the complete weeding of vegetable crops. 


\section{Materials and Methods}

The machine has been designed on the following consideration

\section{Materials}

During this research work for fabrication of weeder, was made of angle iron. Power is taken from the ground as the movement of drum to give movement of drum to give movement of tines. The power is transmitted from drum to tine through chain and sprocket system fitted in two shafts. For power transmission mild steel rods, bush, chains and sprocket were used. Tines were made of mild steel plate. Nut bolts, washer of different sizes were also used for above said purpose. Handle was made of mild steel hollow pipe. The drum wheel was made of mild steel plates.

\section{Description of machine}

The power is generated for weeding purpose from ground by using a drum. The drum is mounted on a shaft, which moves when drum moves. A bicycle chain wheel is also mounted on that shaft which is connected to the free wheel, which is mounted on pinion shaft through a chain.

So when drum moves the pinion shaft as well as tine mounted on pinion shaft also with more peripheral velocity due to difference in number of teeth of chain wheel and gear wheel. The rotary blade enables cutting of weeds and integrating it into soil. The width of coverage of weeder is more than $30 \mathrm{~cm}$ and depth of operation can be adjusted. To fabricate the weeder.

Drum: mild steel flat plate

Frame: angle iron

Handle: mild steel hollow pipe

Shaft: mild steel rod
Bush: mild steel rod

Plate holding tine: mild steel plate

Tine: mild steel plate

\section{Types of tines for rotary weeder}

Many types and shapes of tines have been designed and developed for different directions of operation for rotary tools. There are different shapes of tines for various applications. The rotary tillage tines can be put under four main categories like Pick up tine, Hoe type tine, Slicer type tine, Straight type tine and for this weeder L type Hoe tine has been designed.

\section{Design calculation}

Design requires that a configuration be devised and created to perform a function, at the same time, the configuration should be evaluated for adequate strength, it is better to make assumption and to calculate major loads acting on the component. Therefore for designing the weeder few parts of weeder calculated for their design by assuming or calculating major loads.

\section{Configuration of tines}

In weeder all tines were fitted at angle of $120^{\circ}$ to each other that causes a gap between contacts of one tine alignment to the soil to the simultaneously. Therefore in proposed manual operated rotary weeder all tines were scattered in such a way that in a tine alignment there was only one tine available for contact to the soil at an instant. Therefore angle between one-tine alignment to the other would be kept as $360 / 3=120^{\circ}$.

\section{Tines design}

For the selection of tines for rotary weeder, it is necessary to take into account the maximum peripheral force. 
Maximum peripheral force $\left(\mathrm{F}_{0}\right)=(750 \times \mathrm{hp} \times$ $\left.\mathrm{C}_{\mathrm{z}} \times \mathrm{E}_{\mathrm{c}}\right) / \mathrm{U}$

Where, $\mathrm{hp}=$ an average human power $=0.10$ hp

Human efficiency for machines with concurrent revolution $\left(\mathrm{E}_{\mathrm{c}}\right)=0.8$

Co-efficient including a reverse of implement $\left(\mathrm{C}_{\mathrm{z})}=0.6\right.$

Linear speed of tines $(\mathrm{U})=0.5203$

Maximum peripheral force $\left(\mathrm{F}_{0}\right)=69.19 \mathrm{~N}$

\section{Description and working of weeder}

The power is generated for weeding purpose from ground by using a drum. The drum is mounted on a shaft, which moves when drum moves. A bicycle chain wheel is also mounted on that shaft which is connected to the free wheel, which is mounted on pinion shaft through a chain. So when drum moves the pinion shaft as well as tine mounted on pinion shaft also move with more peripheral velocity due to difference in number of teeth of chain wheel and gear wheel. The rotary blade enables cutting of weeds and integrating it into soil. The width of coverage of weeder is $30 \mathrm{~cm}$ and depth of operation can be adjusted.

\section{Results and Discussion}

A manually operated rotary weeder has been developed for the complete weeding of vegetable crops at Department of Agricultural Engineering, Bihar Agricultural College, Sabour (Bihar). The performance evaluation of the developed rotary power weeder was conducted on the Farm and experimental field of Bihar Agricultural College, Sabour (Bihar). The demonstration of developed weeder has been also conducted in the farmer's field in Sabour and Goradih block of Bhagalpur
(Bihar) district. The performance evaluations were conducted to investigate the effect of weed density on different parameter which is described below.

\section{Effect of soil moisture content on weeding efficiency and draft requirement}

The test was conducted to find out weeding efficiency of vegetable crops like okra, brinjal and tomato in the field having moisture content $19 \%, 16 \%$ and $18 \%$ respectively. Draft was also measured at these soil moisture contents and found to be $18.5 \mathrm{~kg}, 15.6 \mathrm{~kg}$ and $18 \mathrm{~kg}$ respectively. Weeding efficiency obtained at this soil moisture level found to be $77 \%, 80 \%$ and $78 \%$ respectively. From table 1 , we can say that weeding efficiency decreases with increase in soil moisture content.

\section{Effect of speed of operation on weeding efficiency at different level of depth of operation}

Effect of three levels of speed of operation on weeding efficiency at three depth of operation is show in figure 3 and it shows that weeding efficiency increased with increase in depth of operation as well as increase in speed of operation.

\section{Effect of speed of operation on damaged plant percentage at different level of depth of operation}

Effect of speed of operation on damaged plant percent at different level of depth of operation was presented in figure 4 and it is clear that graph shows damaged plant percent increased with increase in speed of operation as well as with increase in depth of operation. This was mainly due to the fact at high speed and depth, maneuverability of weeder became difficult as a result the movement of weeder did not remain a straight line but side ward also, resulting in damage of plants. 
Fig.1 Side view of rotary weeder

Fig.2 Top view tines of rotary weeder
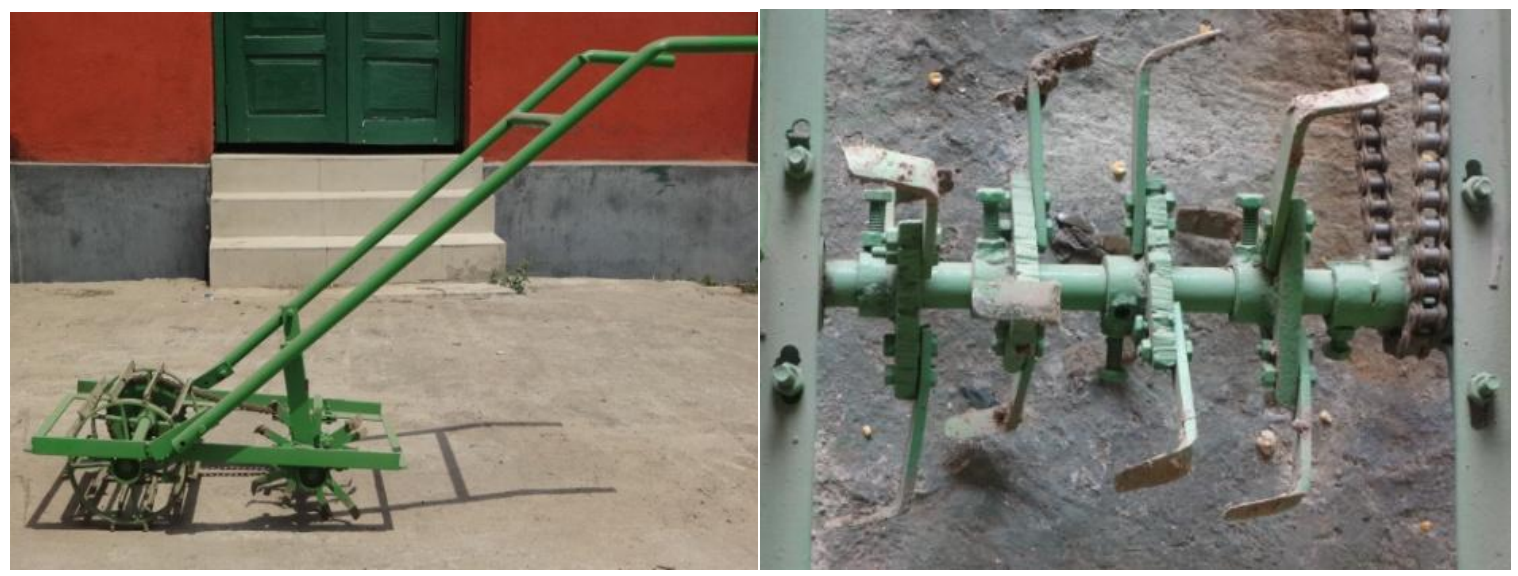

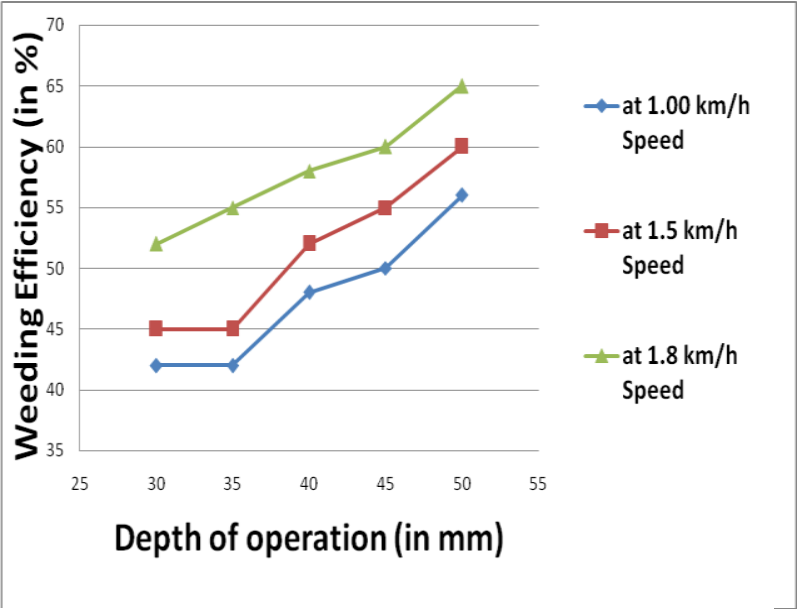

Fig.3 Effect of speed of operation on weeding efficiency

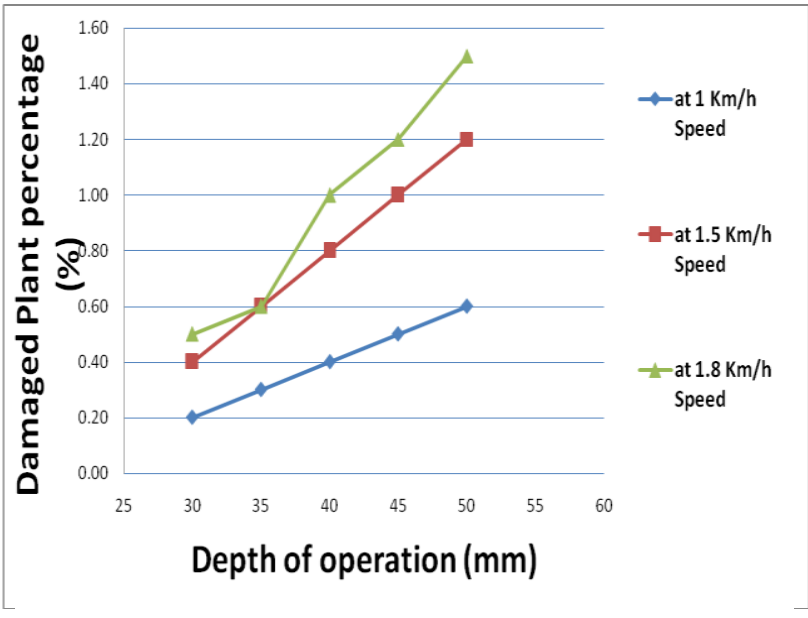

Fig.4 Effect of speed of operation on damaged plant percentage

Table.1 Weeding efficiency and draft requirement at different soil moisture content

\begin{tabular}{|c|c|c|c|c|c|}
\hline Crop & $\begin{array}{l}\text { Soil Moisture } \\
\text { Content } \\
(\%, \text { w.b })\end{array}$ & $\begin{array}{l}\text { Draft } \\
\text { (Kg.) }\end{array}$ & $\begin{array}{l}\text { No of weeds } \\
\text { before weeding } \\
\text { (weeds/m } / \mathbf{m}^{2} \text { ) }\end{array}$ & $\begin{array}{l}\text { No of weeds } \\
\text { after weeding } \\
\left(\text { weeds/m } / \mathbf{m}^{2}\right)\end{array}$ & $\begin{array}{l}\text { Weeding } \\
\text { Efficiency (\%) }\end{array}$ \\
\hline Tomato & 18 & 18.0 & $350-400$ & $75-85$ & 78 \\
\hline okra & 19 & 18.5 & $200-300$ & $45-55$ & 77 \\
\hline Bringal & 16 & 15.6 & $450-500$ & $90-95$ & 80 \\
\hline
\end{tabular}


Table.2 Field capacity at different level of speed of operation

\begin{tabular}{|l|l|l|l|l|l|l|l|}
\hline $\begin{array}{l}\text { Si } \\
\text { No }\end{array}$ & $\begin{array}{l}\text { Distance } \\
\text { travelled } \\
(\mathbf{m})\end{array}$ & $\begin{array}{l}\text { Time taken } \\
\text { to travel } \\
\text { this distance } \\
(\mathbf{s e c})\end{array}$ & $\begin{array}{l}\text { speed } \\
\text { of travel } \\
(\mathbf{k m} / \mathbf{h})\end{array}$ & $\begin{array}{l}\text { Theoretical } \\
\text { field } \\
\text { capacity } \\
(\mathbf{h a} / \mathbf{h})\end{array}$ & $\begin{array}{l}\text { Theoretical } \\
\text { time to } \\
\text { cover } \mathbf{1} \text { ha }\end{array}$ & $\begin{array}{l}\text { Actual } \\
\text { time to } \\
\text { cover } \\
\text { 1 ha field }\end{array}$ & $\begin{array}{l}\text { effective } \\
\text { field } \\
\text { capacity } \\
(\mathbf{h a} / \mathbf{h})\end{array}$ \\
\hline 1 & 50 & 120.07 & 1.50 & 0.045 & 22.22 & 23.44 & 0.042 \\
\hline 2 & 50 & 119.02 & 1.50 & 0.044 & 22.20 & 23.23 & 0.043 \\
\hline 3 & 50 & 121.08 & 1.50 & 0.046 & 22.34 & 23.11 & 0.043 \\
\hline 4 & 50 & 119.83 & 1.50 & 0.043 & 21.68 & 24.08 & 0.041 \\
\hline 5 & 50 & 122.05 & 1.50 & 0.047 & 22.87 & 22.85 & 0.043 \\
\hline Avg & $\mathbf{5 0}$ & $\mathbf{1 2 0 . 4 1}$ & $\mathbf{1 . 5 0}$ & $\mathbf{0 . 0 4 5}$ & $\mathbf{2 2 . 2 6}$ & $\mathbf{2 3 . 3 4}$ & $\mathbf{0 . 0 4 2}$ \\
\hline
\end{tabular}

Appendix.1 Field performance of weeder in brinjal crop in different field and on different soil moisture level

\begin{tabular}{|l|l|l|l|l|l|}
\hline Field & $\begin{array}{l}\text { Soil moisture } \\
\text { content }(\boldsymbol{\%}, \mathbf{w . b})\end{array}$ & $\begin{array}{l}\text { Draft } \\
(\mathbf{k g})\end{array}$ & $\begin{array}{l}\text { No of weeds before } \\
\text { Weeding }\left(\mathbf{w e e d s} / \mathbf{m}^{2}\right)\end{array}$ & $\begin{array}{l}\text { No of weeds after } \\
\text { weeding }\left(\mathbf{w e e d s} / \mathbf{m}^{2}\right)\end{array}$ & $\begin{array}{l}\text { Weeding } \\
\text { Efficiency }(\boldsymbol{\%})\end{array}$ \\
\hline 1 & 18 & 18 & $350-400$ & $75-85$ & 74 \\
\hline 2 & 19 & 18.5 & $200-300$ & $45-55$ & 77.5 \\
\hline 3 & 17 & 17 & $180-200$ & $42-52$ & 76 \\
\hline 4 & 16 & 15.6 & $450-500$ & $90-95$ & 80 \\
\hline 5 & 17 & 17.5 & $240-320$ & $48-58$ & 80 \\
\hline
\end{tabular}

Appendix.2 Specifications of developed manually operated rotary weeder

\begin{tabular}{|l|l|}
\hline $\begin{array}{l}\text { Overall Dimension of Rotary } \\
\text { weeder }\end{array}$ \\
\hline Overall Length & $1050 \mathrm{~mm}$ \\
\hline Overall Width & $300 \mathrm{~mm}$ \\
\hline Overall Height & $400 \mathrm{~mm}$ \\
\hline
\end{tabular}

\begin{tabular}{|l|l|}
\hline $\begin{array}{l}\text { Overall Dimension of Rotary } \\
\text { weeder }\end{array}$ \\
\hline Overall Length & $1050 \mathrm{~mm}$ \\
\hline Overall Width & $300 \mathrm{~mm}$ \\
\hline Overall Height & $400 \mathrm{~mm}$ \\
\hline
\end{tabular}

\begin{tabular}{|l|l|}
\hline \multicolumn{2}{|c|}{ Frame Specification of Rotary Weeder } \\
\hline Length of frame & $475 \mathrm{~mm}$ \\
\hline $\begin{array}{l}\text { Width of main rectangular } \\
\text { frame }\end{array}$ & $410 \mathrm{~mm}$ \\
\hline Height of frame & $75 \mathrm{~mm}$ \\
\hline Size of material & $30 \times 30 \times 5 \mathrm{~mm}$ \\
\hline Type of Material & L-Angle iron \\
\hline Material of Construction & Mild steel \\
\hline
\end{tabular}




\begin{tabular}{|l|l|}
\hline \multicolumn{2}{|c|}{ Weeding Unit Specification } \\
\hline Type & L-type \\
\hline Length & $10 \mathrm{~cm}$ \\
\hline Working Length & $14 \mathrm{~cm}$ \\
\hline Width at tip & $8 \mathrm{~mm}$ \\
\hline Thickness & $4 \mathrm{~mm}$ \\
\hline Direction of Revolution & Anticlockwise \\
\hline Vertical crop clearance & 75 mm \\
\hline Material of construction & Mild steel \\
\hline
\end{tabular}

Field capacity at different level of speed of operation

Field capacity was calculated at three levels of speed $(1 \mathrm{Km} / \mathrm{h}, 1.5 \mathrm{Km} / \mathrm{h}$ and $1.8 \mathrm{Km} / \mathrm{h})$ and depth of operation of $35 \mathrm{~mm}$. At $1.5 \mathrm{~km} / \mathrm{h}$ it was found that this machine worked more efficiently as compared to $1 \mathrm{Km} / \mathrm{h}$ and 1.8 $\mathrm{Km} / \mathrm{h}$, operator feels hard to operate the weeder and tired just after half an hour of operation. Therefore this weeder is not suitable for $1.8 \mathrm{Km} / \mathrm{h}$ speed of operation or more. We have calculated weeding efficiency at $1.5 \mathrm{Km} / \mathrm{h}$ speed of operation. The field capacity of the manually operated rotary weeder was calculated at optimum speed of $1.5 \mathrm{Km} / \mathrm{h}$, which is tabulated in the table 2 .

Comparison of cost of weeding with designed rotary weeder and conventional methods

The observed field capacity of rotary weeder was found $0.042 \mathrm{ha} / \mathrm{h}$. The cost of weeding operation by using this implement was calculated to be Rs. 16221/ha. The conventional methods using khurpi or other conventional tools require 20 labours per day for 1 ha of field. This works out to cost of weeding per hectare field as Rs. 40000/-. Saving in cost of weeding by using manually

\begin{tabular}{|c|c|}
\hline \multicolumn{2}{|c|}{ Details of Power Transmission System } \\
\hline \multicolumn{2}{|c|}{$\begin{array}{l}\text { Power transmission from drum wheel to } \\
\text { Main shaft through bushes }\end{array}$} \\
\hline \multicolumn{2}{|c|}{$\begin{array}{l}\text { Power transmission from main shaft to tine } \\
\text { holding shaft through chain sprocket system }\end{array}$} \\
\hline Diameter of Tine holder shaft & $40 \mathrm{~mm}$ \\
\hline No. of teeth on big gear & 43 \\
\hline No. of teeth on main gear & 16 \\
\hline \multicolumn{2}{|c|}{ Type of chain: standard pitch roller chain } \\
\hline Material of construction & 02 \\
\hline
\end{tabular}

operated rotary weeder as compared to conventional method was found to be around $60 \%$. A machine has been developed for weeding of vegetable crops like okra, tomato, brinjal and vegetables having crop distance more than $25 \mathrm{~cm}$. The weeding efficiency of weeder was found as $80 \%$, at soil moisture content level of $16 \%$. The percentage $(\%)$ plant damaged was found at this weeding efficiency in between 0.6 to $1.2 \%$.

Weeding efficiency increases with decrease in soil moisture content through this developed weeder. Maximum weeding efficiency is obtained at $1.5 \mathrm{Km} / \mathrm{h}$ speed of operation and $35 \mathrm{~mm}$ depth of operation. The observed field capacity of weeder was found $0.042 \mathrm{ha} / \mathrm{h}$ at $1.5 \mathrm{~km} / \mathrm{h}$ speed of operation at a depth of 35 $\mathrm{mm}$. The cost of weeding operation by using manually operated rotary weeder was calculated at Rs. 16221/ha which was $60 \%$ lower than the conventional method of weeding e.g., sickle, hasuwa, or khurpi.

\section{References}

Anyawu, A. C., Anyawu, B. O. and Anyawu, A. A. 1976. Agriculture for school certificate. Africana Education Publication (Nig.) in association with FEP Int. Ltd. 
ASAE, 1986. Agricultural Machinery Management Data. D230-4. American Society of Agricultural Engineers. Pp. 159163

Bainer, R., Barger, E. L. and Kepner, R. A. (1978). Principles of Farm Machinery. Avi publication Co. Inc. Westport, Connecticus. 3rd Edition.

Blasco J., Aleixos N., Roger J., Rabatel E. and Molto E. (2002) Robotic weed control using machine vision. Biosystems Engineering, 83 (2), 149-157.

Buckingham, F. 1976. Fundamentals of machine Operation. John Deere Service Publication, Moline, Iowa, USA

Fogelberg F. and Kritz G. (1999) Intra-row weeding with brushes on vertical Axesfactors influencing in-row soil height. Soil and Tillage Research, 50, 149-157.

Hunt, D. (1983). Farm Power and Machinery Management. 8th Edition. Iowa State University Press. AMES. Iowa USA.

Igbeka, J. C. 1984. Development in Rice Production Mechanization. AMA. 10(1). 27-32. Kepner, R. A., Bainer, R. and Barger, E. L. 1978. Principles of farm machinery, 3rd edition, AVI publication Co., INC., Westport, Connecticut.

Kurstjens D., Perdok U. and Goense D. (2000) Selective uprooting by weed harrowing on sandy soils. Weed research, 40, 431-447.

Kurstjens D. A. G. and Perdok U. D. (2000). The selective soil covering mechanism of weed harrows on sandy soils. Soil and Tillage Research, (55), 193-206.

Lavabre, E. M. (1991). Weed Control. Macmillian Education Ltd., London

Liljedah, J. B., Carleton, P. K. and Smith, D. W. (1979). Tractor and their Power Units. 3rd Edition. John Wiley and Sons. New York. 136
Nganilwa, Z. M., Makungu, P. J. and Mpanduji, S. M. 2003. Development and Assessment of an Engine Powered hand held weeder in Tanzania. International Conference on Industrial Design Engineering, UDSM, Dare salam.

Njoku, P. C. 1996. The Role of Universities of Agriculturei Appropriate Manpower Development for Weed Management in Agriculture. Nigerian Journal of Weed Science. Vol. 9, 65.

Odigboh, E. U. and Ahmed, S. F. 1979. Development of a Ridge Profile Weeder. AMA. 21(1): 43-48

Oni, K. C. (1990). Performance Analysis of a Ridge Profile Weeder. Proceeding of Nigerian Society of Agricultural Engineers. 3: 189-199.

Parish S. (1990) A review of non-chemical weed control techniques. Biological Agriculture and Horticulture, 7, 117-137.

Pullen D. and Cowell P. (1997) An evaluation of the performance of mechanical Weeding mechanisms for use in high speed inter-row weeding for Arable Crops. Journal of Agricultural Engineering Research, 67, 2734.

Rangasamy, K., Balasubramanian, M. and Swaminuthan, K. R. 1993. Evaluation of Power Weeder Performance. AMA. 24(4): 16-18.

Singh, C. M., Moodey, J. and Cho, S. C. 1981. The Efficiency of the Rolling Weeder in Controlling Weeds in Dry-Seeded Rainfall Rice. Paper presented at the cropping system seminar. International Rice Res. Institute. Los Banos, Phillipines, Feb.24.

Singh, C. M., Moodey, J. and Cho, S. C. 1985. Weed Control through Inter-Row Cultivation in Upland Rice. AMA. 16(3): 34-40.

\section{How to cite this article:}

Satish Kumar, Ashok Kumar and Sanoj Kumar. 2017. Performance Evaluation of Developed Manually Operated Rotary Weeder for Vegetable Crops. Int.J.Curr.Microbiol.App.Sci. 6(11): 4012-4019. doi: https://doi.org/10.20546/ijcmas.2017.611.470 